
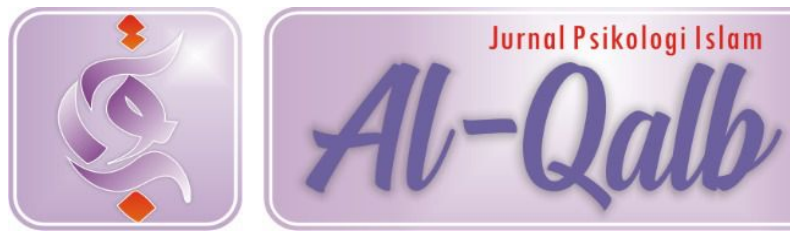

EISSN : 2686-326X

ISSN : 2085-8647

https://ejournal.uinib.ac.id/jurnal/index.php/alqalb/index

\title{
PENGAMBILAN KEPUTUSAN DITINJAU DARI MANAJEMEN DIRI DAN KEMATANGAN EMOSI
}

Received: $26^{\text {th }}$ March 2019; Revised: $10^{\text {th }}$ April 2019; Accepted: $24^{\text {th }}$ April 2019

\author{
Muhammad Satar \\ Institut Agama Islam Negeri Parepare \\ Email: muhammadsatar.ms@gmail.com \\ Nur Aisyiah Yusri \\ Universitas Islam Negeri Imam Bonjol \\ Padang \\ Email: ainyoes@yahoo.co.id
}

\begin{abstract}
The orientation of decision making is actually supported also by one's experience, while attitudes toward experience itself are related to one's emotional maturity. Emotional maturity is a valuable capital. People who have more mature emotions will be able to choose what is best and what they must avoid. The emotional maturity of an employee can be seen from the way he faces challenges, how his responsibilities towards work, and how his life views the world, so that the difficulties faced in making a decision will be lighter than employees who have lower emotional maturity. Emotional maturity is characterized by how conflicts are solved, and how difficulties are handled. People who are adults, in this case are emotionally mature, see their difficulties not as catastrophe, but as challenges, so that when he is faced with a situation where he has to choose an alternative offered to him, armed with the knowledge and experience he has it will be easier to make decisions that are considered most appropriate. He is willing to take risks, but still based on the most appropriate estimates that can be obtained.
\end{abstract}

Keywords: decision-making, self-management, emotional maturity

\section{Pendahuluan}

Globalisasi menuntut setiap organisasi untuk segera tanggap dalam melakukan perubahan dan langkah yang lebih maju agar dapat bertahan dalam lingkungan yang terus berkembang. Perubahan dan pergerakan ke arah yang lebih baik ini, tentu saja memerlukan perencanaan yang matang dan pengambilan keputusan yang tepat. Pengambilan keputusan adalah fakta yang harus dihadapi baik dalam kehidupan personal maupun dalam bisnis. Kita membuat banyak keputusan setiap harinya. Kadangkala beberapa keputusan begitu mudah diputuskan, tetapi banyak pula yang kompleks. Bila dicermati, banyak perusahaan ataupun organisasi yang "gulung tikar" karena kesalahan dalam mengambil keputusan. Saat diamati lebih lanjut, ternyata banyak kasus kesalahan pengambilan keputusan ini yang bermula dari perencanaan yang kurang matang, tergesa-gesa ataupun pemilihan alternatif pemecahan masalah yang tidak tepat.

Kemampuan dalam mengambil keputusan membantu kita mengarungi kehidupan, menghindari masalah yang mungkin timbul, dan memperluas cakrawala pandang kita (Pettigrew, 2009). Banyak masalah pengambilan keputusan dalam organisasi yang membutuhkan motivasi, kreativitas, penerimaan, pengetahuan, dan kecakapan (Brown, Colville, \& Pye, 2014; 
Shepherd \& Rudd, 2014). Pengambilan keputusan merupakan pemilihan tindakan dari sejumlah alternatif yang ada (Tjader, May, Shang, Vargas, \& Gao, 2014;Davenport, 2015). Birkland (2016) memberikan enam langkah dalam proses pengambilan keputusan, yaitu menetapkan masalah, mengidentifikasi kriteria keputusan, mengalokasi bobot pada kriteria, mengembankan alternatif, evaluasi alternatif dan memilih alternatif terbaik.

Fungsi pengambilan keputusan dalam sebuah organisasi tidak hanya dijalankan oleh seorang yang berkedudukan sebagai manajer atau pimpinan. Pengambilan keputusan terjadi pada semua bidang dan tingkat kegiatan serta pemikiran manusia (Chiu, Liang, \& Turban, 2014). Pengambilan keputusan yang efektif sangat penting baik bagi organisasi maupun individu. Perubahan dalam struktur, proses, teknologi, dan ketersediaan data dalam organisasi akan meningkatkan keinginan anggota dalam semua level organisasi untuk membuat keputusan, dan hal ini membuat mereka bekerja lebih efektif.

Penelitian dari Janssen, Voort, dan Wahyudi (2017) yang mencoba mengetes teori multilevel dari pengambilan keputusan dalam kelompok menunjukkan bahwa validitas teori multilevel ini hanya dapat digeneralisasikan pada level khusus anggota staff. Penelitian mengenai pengambilan keputusan pada kelompok yang dilakukan Shepherd, Williams, dan Patzelt (2014) melalui simulasi komputer menunjukkan bahwa pengambilan keputusan yang paling akurat terjadi ketika pimpinan dan staf keduanya memiliki kecermatan dan ketelitian tinggi. Sedang reaksi yang paling lemah terjadi beragam, tergantung dari ketelitian rendah.

Setiap orang akan selalu dihadapkan pada beberapa alternatif pilihan dan dia harus memilih salah satu yang terbaik dengan terlebih dulu mempertimbangkan keuntungan dan kerugiannya agar keputusan yang diambilbenar-benar keputusan yang terbaik. Kendala atau permasalahan yang sering dihadapi seseorang yang tergabung dalam suatu organisasi atau perusahaan dalam mengambil keputusan salah satunya dapat dipecahkan dengan adanya kemampuan (ability) dalam melihat suatu masalah. Dalam pengambilan keputusan seseorang harus memiliki kemampuan untuk memilih hal yang benar dan salah. Selain kemampuan penguasaan terhadap masalah, pengambilan keputusan juga ditentukan oleh faktor kepribadian, dalam hal ini adalah manajemen diri dan kematangan emosi.

Disadari atau tidak, kemampuan manajemen diri berpengaruh terhadap kemampuan seseorang dalam mengambil keputusan. Seorang karyawan yang dapat memanajemen dirinya dengan baik tidak akan haluan dalam bertindak. Romiszowski (2016) mengemukakan bahwa kesempatan untuk melakukan manajemen diri dalam pekerjaan merupakan suatu bentuk tanggung jawab. Seperti halnya orang bertanggung jawab pada keputusan yang diambilnya. Anderson (2017) mengemukakan manajemen diri adalah suatu prosedur yang menuntut seseorang untuk mengarahkan atau menata tingkah lakunya sendiri.

Dewasa ini semakin banyak karyawan yang terjebak dalam proses pengaturan dirinya sendiri. Mereka merasa kesulitan untuk membagi waktu yang digunakan untuk mengerjakan pekerjaan kantor yang rasanya semakin menumpuk. Bila dicermati, seorang karyawan yang dapat memanajemen dirinya dengan baik tidak akan kehilangan arah ke mana ia akan melangkah. Karyawan yang mampu mengatur tingkah lakunya sendiri dan memiliki target yang jelas akan mampu membuat pertimbangan dan kemudian mengambil keputusan yangtepat baik bagi dirinya maupun perusahaan tempat ia bekerja. Orang yang memiliki kemampuan pemantauan dan evaluasi diri yang baik, tentu akan dapat memilih dan memutuskan yang terbaik bagi dirinya dan tidak merugikan orang di sekitarnya.

Orientasi pengambilan keputusan sebenarnya didukung pula oleh pengalaman 
seseorang, sedangkan sikap terhadap pengalaman itu sendiri berkaitan dengan kematangan emosi seseorang. Kematangan emosi adalah sebuah modal yang berharga. Orang yang memiliki emosi yang lebih matang akan dapat memilah dan memilih apa yang terbaik dan yang harus dihindarinya. Kematangan emosi seorang karyawan dapat dilihat dari caranya menghadapi tantangan, bagaimana tanggung jawabnya terhadap pekerjaan, dan bagaimana pandangan hidupnya tentang dunia ini, sehingga kesulitan yang dihadapi dalam mengambil sebuah keputusan akan lebih ringan dibanding karyawan yang memiliki kematangan emosi lebih rendah. Kematangan emosi ditandai dengan bagaimana konflik dipecahkan, dan bagaimana kesulitan ditangani (Dror, 2017). Orang yang sudah dewasa, dalam hal ini adalah dewasa secara emosi memandang kesulitan-kesulitannya bukan sebagai malapetaka, tetapi sebagai tantangan-tantangan, sehingga saat ia dihadapkan pada situasi dimana ia harus memilih salah satu alternatif yang disodorkan padanya, berbekal pengetahuan dan pengalaman yang dimiliki dia akan lebih mudah mengambil keputusan yang dianggap paling sesuai (Dror, 2017). Dia bersedia memikul resiko, namun tetap berdasarkan perkiraan-perkiraan yang paling tepat yang dapat diperolehnya.

Pengambilan keputusan merupakan tugas yang cukup berat, jika tidak didorong kematangan emosi dan manajemen diri yang tinggi maka seseorang akan sulit mengambil suatu keputusan. Kematangan emosi dan kemampuan manajemen diri yang tepat akan membawa seseorang ke arah rasa percaya diri yang mantap, sehingga proses dan tahapan dalam pengambilan keputusan dapat dilakukan secara maksimal. Banyak karyawan yang terjebak dan salah langkah dalam mengambil keputusan karena hanya mementingkan emosi sesaat sehingga mereka melupakan langkahlangkah penting yang seharusnya dilakukan dan prosedur yang seharusnya dilewati.
Berdasarkan uraian di atas, setidaknya terdapat dua hal yang potensial yang dapat mempengaruhi suatu proses orientasi pengambilan keputusan yang efektif, yaitu kemampuan pemecahan terhadap masalah, dan kemampuan afeksi atau kepribadian yang antara lain adalah manajemen diri dan kematangan emosi. Kekurang-mampuan karyawan dalam manajemen dirinya dan emosi yang kurang matang akan mengakibatkan kesalahan pengambilan keputusan, keputusan yangdiambil tidak sesuai dengan subjek masalahnya, sehingga tidak dapat mengatasi masalah yang sebenarnya. Keadaan tersebut dapat diminimalkan dengan usaha organisasi menciptakan lingkungan yang dapat membuat karyawan mampu meningkatkan kemampuan manajemen dirinya, belajar meningkatkan kematangan emosinya, dan menghargai pengambilan keputusan.

Memperhatikan uraian di atas, perlu kiranya untuk ditelaah lebih lanjut tentang beberapa faktor yang mempengaruhi proses orientasi pengambilan keputusan, yaitu seberapa besar peran manajemen diri dan kematangan emosi terhadap proses orientasi pengambilan keputusan.

\section{Kajian Teori \\ Pengambilan Keputusan}

Menurut Mardani, et al. (2015) pengambilan keputusan dimulai saat ada keputusan bahwa terdapat sebuah masalah yang harus dihadapi. Collier (2015) mengatakan bahwa pengambilan keputusan adalah suatu proses terjadinya identifikasi masalah, menetapkan tujuan pemecahan, pembuatan keputusan awal, pengembangan dan penilaian alternatif-alternatif, serta pemilihan salah satu alternatif yang kemudian dilaksanakan dan ditidaklanjuti.

Sharma, Mithas, dan Kankanhalli (2014) menyatakan pengambilan keputusan sebagai kegiatan pemilihan diantara berbagai alternatif yang tersedia. Beach (2014) menjelaskan pengambilan keputusan sebagai proses pemikiran dan pertimbangan yang mendalam 
yang dihasilkan dalam sebuah keputusan. Pengambilan keputusan merupakan sebuah proses dinamis yang dipengaruhi oleh banyak kekuatan termasuk lingkungan organisasi dan pengetahuan, kecakapan dan motivasi. Witte dan Davis (2014) mendefinisikan pengambilan keputusan sebagai pemilihan tindakan dari sejumlah alternatif yang ada. Senada dengan ituLuhmann, Baecker, dan Barrett (2018) mendefinisikan pengambilan keputusan adalah "process of identifying a problem or opportunityand chooshing among alternative courses of action." Menurut Gerston (2014) seorang pembuat keputusan adalah seorang pemecah masalah, yaitudengan memilih salah satu alternatif-alternatif yang tersedia, atau menemukan alternatif lain yang secara berbeda dari alternatif yang ada sebelumnya.

Putnam, Fairhurst, dan Banghart (2016) mengemukakan bahwa pengambilan keputusan adalah suatu proses dimana beberapa kemungkinan dapat dipertimbangkan dan diprioritaskan, yang hasilnya dipilih berdasarkan pilihan yang jelas dari salah satu alternatif kemungkinan yang ada. Graham, Harvey, dan Puri (2015) mendefinisikan pengambilan keputusan sebagai suatu respon yang sesuai dari seseorang yang berinteligensi pada suatu situasi yang membutuhkan tindakan yang tepat. Sedangkan menurut ahli lain Maxwell, Rotz, dan Garcia (2016) pengambilan keputusan adalah suatu tindakan memilih salah satu alternatif yang ada atas pertolongan para manajer yang menentukan suatu tindakan pada situasi yang telah ditentukan.

Snyder dan Diesing (1997) berpendapat bahwa pengambilan keputusan adalah proses pemilihan suatu arah tindakan untuk memecahkan suatu masalah tertentu. Untuk menghasilkan suatu keputusan yang tepat maka Smith (2014) dalam penelitian mereka menjelaskan bahwa para pengambil keputusan yang dengan tujuan untuk menghasilkan suatu keputusan yang akurat harus berhati-hati dengan informasi yang tidak konsisten dari karyawan, sehingga para pengambil keputusan itu dapat mengenali dan mendapatkan suatu keputusan yang tepat sebagai hasil pemilihan dari beberapa alternatif pilihan yang tersedia. Zsambok dan Klein (2014) menambahkan bahwa keputusan yang terbaik adalah keputusan yang diambil secara sengaja dan disertai pemikiran yang matang.

Dalam penelitian ini pengertian pengambilan keputusan adalah proses pengakhiran dari proses pemikiran tentang suatu masalah dengan menetapkansatu pilihan yang dianggap paling akurat dari beberapa alternatif pilihan guna mencapai tujuan yang diinginkan.

Menurut Tseng dan Hung (2014)gaya pengambilan keputusan mempengaruhi pendekatan seeorang dalam membuat pengambilan keputusan. Gaya pengambilan keputusan merefleksikan kombinasi bagaimana seseorang menerima dan mengkomprehensikan stimulus yang diperoleh yang kemudian dipilihnya dalam rangka merespon informasi-informasi yang ada.

Ada dua dimensi yang berbeda yang digunakan dalam pengambilan keputusan, yaitu:

\section{a. Value Orientation (VO);}

Saat mengambil keputusan, individu lebih memfokuskan pada unsur teknis dan tugas yang harus dilakukan, atau pada orang-orang dan lingkungan sosialnya.

b. Tolerance of Ambiguity (TfA)

Mengindikasikan sejauh mana kebutuhan yang dimiliki seseorang dalam mengatur dan mengontrol kehidupannya.

Gaya pengambilan keputusan dalam penelitian ini sependapat dengan uraian Kocet dan Herlihy (2014), bahwa setiap karyawan memiliki gaya pengambilan keputusan yang berbeda-beda. Bisa jadi mereka memiliki gaya pengambilan keputusan secara directive, analitycal, conceptual atau bahkan behavioral. Masing-masing gaya pengambilan keputusan memiliki kelebihan dan kekurangannya sendiri. Seorang karyawan yang telah mengetahui gaya pengambilan keputusannya dapat 
meningkatkan atau memperbaiki dengan mengkombinasikan dengan gaya yang lain agar keputusan yang diambil dapat sesuai dengan yang diharapkan.

Proses pengambilan keputusan mencakup beberapa langkah yang dikemukakan oleh banyak ahli psikologi organisasi dan manajemen. Berikut ini akan dibahas beberapa pendapat para ahli tentang langkah-langkah tersebut. Pengambilan keputusan merupakan suatu proses pembuatan pilihan dari sejumlah alternatif yang didalamnya terdapat elemen-elemen informasi, tujuan, pilihan tindakan, kemungkinan tindakan-hasil, nilai yang berhubungan dengan tujuan dan setiap hasil, dan salah satu pilihan tindakan(Shaik \& Abdul-Kader, 2014).

Menurut Monghasemi, Nikoo, Fasaee, dan Adamowski (2015) menyatakan ada lima langkah dalam proses pengambilan keputusan yaitu recognizing and defining the problem,information search, alternatif generation, evaluation, dan implementation and assessment. Betsch (2014) memberikan enam langkah dalam prosespengambilan keputusan yaitu menetapkan masalah, mengidentifikasi kriteria keputusan, mengalokasi bobot pada kriteria, mengembankan alternatif, evaluasi alternatif, dan memilih alternatif terbaik.

Berdasarkan beberapa teori proses pengambilan keputusan yang telah dikemukakan, Govindan, Rajendran, Sarkis, dan Murugesan (2015) merangkumnya dalam proses yang lebih rinci, yaitu:

a. Mengidentifikasi persoalan. Sebuah syarat yang perlu bagi keputusan adalah persoalan. Proses pangambilan keputusan umumnya dimulai setelah permasalahan diidentifikasi,setelah masalah diidentifikasi, tujuan dapat diformulasikan;

b. Menentukan tujuan dan analisis masalah. Analisis masalah, penetapan tujuan dan sasaran secara memadai akan menentukan hasil yang akan dicapai; c. Mengembangkan berbagai alternatif solusi. Sebelum mengambil keputusan, harus dikembangkan beberapa alternatif solusi yang dapat dilaksanakan dan harus dipertimbangkan konsekwensinya yang mungkin terjadi dari tiap-tiap alternatif tersebut;

d. Mengevaluasi alternatif. Setelah alternatif dikembangkan, maka alternatif harus dievaluasi dan dibandingkan;Memilih alternatif terbaik. Alternatif yang terbaik adalah dalam hubungannya dengan sasaran atau tujuan yang hendak dicapai, jadi tujuan memilih alternatif adalah memecahkan persoalan agar dapat mencapai tujuan dan sasaran yang telah ditentukan;

e. Melaksanakan keputusan. Jika salah satu alternatif yang terbaik telah dipilih, maka keputusan tersebut kemudian harus diterapkan. Melaksanakan keputusan hendaknya dilakukan secara efektif untuk mencapai sasaran yang telah ditetapkan; dan

f. Evaluasi. Mekanisme sistem evaluasi perlu dilakukan agar apa yang diharapkan dari keputusan tersebut dapat terealisir. Evaluasi didasarkan atas sasaran dan tujuan yang telah ditetapkan.

Beberapa pendekatan terhadap pengambilan keputusan telah disebutkan di atas. Pendekatan mana yang terbaik tergantung pada sifat masalah, tersedianya waktu, biaya masing-masing strategi, dan keterampilan mental dari pengambil keputusan (Rezaei, Best-worst multi-criteria decision-making method: Some properties and a linear model, 2016).

\section{Manajemen Diri}

Usaha untuk mencapai hidup sukses perlu berpegang pada strategi tertentu, salah satu di antaranya yaitu manajemen diri. Breevaart, Bakker, dan Demerouti (2014) 
mengemukakan manajemen diri adalah suatu prosedur yang menuntut seseorang untuk mengarahkan atau menata tingkah lakunya sendiri. Prosedur ini melibatkan subjek dalam beberapa tahap, yaitu:

a. menentukan sasaran tingkah laku yang hendak dicapai

b. memonitor tingkah lakunya dengan cara menentukan sendiri prosedur yang hendak dipakai untuk memonitor perkembangan yang sudah dicapaimengevaluasi perkembangan tingkah lakunya.

Kostera (2014) mengemukakan bahwa kesempatan untuk melakukan manajemen diri dalam pekerjaan merupakan suatu bentuk tanggung jawab. Manajemen diri merupakan suatu prosedur yang mengharuskan orang menentukan target kerja yang hendak dicapainya, memonitor dan mengevaluasinya. Mládková (2015)menguraikan bahwa manajemen diri adalah suatu metode yang digunakan oleh seseorang dalam bekerja dengan cara melakukan pengontrolan terhadap hasil kerja yang dilakukan oleh dirinya sendiri tanpa harus ada kontrol dari luar. Dengan menggunakan catatan tentang hasil kerja yang sudah lalu, mereka menilai dan mengevaluasi hasil kerja yang baru dicapainya (Marinescu, 2017).

Manajemen diri, menurut Gorman dan Pauleen (2016) adalah segenap kegiatan dan langkah mengatur dan mengelola diri sendiri sebaik-baiknya, sehingga mampu membawa ke arah tercapainya tujuan hidup yang telah ditetapkan oleh individu yang bersangkutan. Strategi yang pertama dan utama dalam manajeman diri adalah berusaha mengetahui diri sendiri dengan segala kekurangan dan kelebihan yang dimiliki dengan segenap kekuatan dan potensinya Gorman dan Pauleen (2016).

Pengertian manajemen diri dalam penelitian ini adalah suatu prosedur yang mengarahkan manusia untuk dapat mengatur tingkah lakunya sendiri, menentukan target kerja yang hendak dicapai, memonitor, serta mengevaluasi kerja yang telah dilakukan melalui catatan dari hasil kerja terdahulu. Manajemen diri yang tepat, dapat membantu menciptakan atau mengkreasi masa depan agar lebih cerah.

Pribadi yang tangguh sangat dibutuhkan agar dapat memiliki manajemen diri yang baik. Cummings dan Worley (2015) mengemukakan ada 8 faktor yang harus dipenuhi oleh seseorang bila ingin memiliki manajemen diri yang baik, meliputi:

a. Kehangatan (warmth) Individu yang memiliki kehangatan tinggi biasanya akan mudah dalam berhubungan dengan orang lain, mudah menyesuaikan diri dengan lingkungan sosial, misalnya karyawan akan lebih mudah menyesuaikan diri dalam berbagai kondisi di kantor.

b. Kecerdasan (inteligence)

Kecerdasan yang dimaksud bukan hanya terbatas pada kemampuan menyelesaikan persoalan akademis tetapi juga kemampuan dalam menyelesaikan masalah sosial, misalnya karyawan akan dapat menyelesaikan permasalahan yang dihadapi dalam pekerjaan, kreatif, dan berwawasan luas.

c. Keberanian (boldness)

Individu yang memiliki keberanian tinggi mampu mengambil keputusan dengan cepat, meskipun belum tentu keputusannya benar. Ciri lainnya adalah enerjik dan tidak suka mengisolasi diri, misalnya karyawan dapat memutuskan saat yang tepat untuk menikmati saat istirahatnya dan mengerjakan tugas kantornya.

d. Kestabilan emosi (emotional stability) Orang dengan kestabilan emosi yang tinggi jarang mengalami kecemasan. Bentuk konkritnya adalah jarang mengalami kecelakaan dalam bekerja, dan

kehidupan sehari-hari, misalnya wanita karir yang dapat mengatur diri dan 
kegiatannya dengan baik tidak akan terganggu konsentrasinya saat bekerja, emosinya tidak mudah meledak, dan sabar.

e. Ketajaman berpikir (srewdness)

Berhubungan erat dengan kecerdasan. Ciri orang yang berpikiran tajam adalah mampu mengatasi masalahnya dan dapat berunding, misalnya karyawan dapat dengan cepat mengatasi masalah yang timbul yang diakibatkan oleh pekerjaannya, berani beradu pendapat, dan dapat menciptakan inovasi baru

f. Rasa aman (security) Individu yang memiliki rasa aman tidak akan mudah putus asa, dan tidak suka menyendiri, misalnya karyawan merasa aman dalam pekerjaan, dan hal tersebut membuatnya tidak mudah putus asa menghadapi masalah yang muncul dalam perkerjaan, percaya diri, dan mampu menghargai dirinya sendiri.

g. Pemenuhan kebutuhan diri (selfsufficiency)

Individu yang memiliki pemenuhan kebutuhan tinggi, tidak tergantung pada orang lain. Umumnya mereka sukses dalam pekerjaan yang tidak melibatkan banyak orang, misalnya karyawan akan lebih mudah mengoptimalkan kemampuannya bila mengerjakan pekerjaan yang menjadi keahliannya, tidak bergantung pada orang lain, dan mandiri.

h. Disiplin diri (self-discipline)

Individu yang memiliki disiplin diri yang tinggi biasanya dapat mengontrol diri, misalnya karyawan dapat mengontrol atau mengatur waktu dankegiatannya di kantor maupun di rumah, sehingga tidak saling bertabrakan, tidak pernah terlambat masuk kerja, dan memiliki jadwal harian yang selalu ditaatinya.

Faktor di atas harus diikuti pula oleh strategi yang mantap dalam melakukan manajemen diri. Ada beberapa macam strategi untuk melakukan manajemen diri, seperti dikemukakan oleh Linstead, Marechal, dan Griffin (2014). Langkahnya antara lain:

a. Memotivasi diri;

Sering dikenal dengan self-

motivation yaitu dorongan

psikologis yang merangsang

seseorang untuk melakukan

berbagai kegiatan dalam rangka

mencapai tujuan yang didambakan, misalnya karyawan memotivasi

dirinya agar dapat melaksanakan kegiatan di kantor dengan baik tanpa mengganggu kegiatan hariannya.

b. Pengorganisasian diri;

Disebut juga self-organizing yaitu pengaturan yang baik terhadap pikiran, energi, waktu, tempat, benda, dan sumber daya lain dalam hidup sehingga semua dapat berjalan dengan tertib dan lancar, misalnya karyawan mengorganisasikan dirinya sedemikian rupa sehingga dia dapat mengambil keputusan, tanpa meninggalkan tugas dan pekerjaannya di kantor.

c. Pengendalian diri

Sering pula disebut sebagai self-control yaitu berbagai tekad dan langkah untuk mendisiplinkan kemauan, memacu semangat, mengikis keseganan, dan mengerahkan energi untuk melaksanakan yang harus dilaksanakan sesuai tujuan yang didambakan, misalnya karyawan berusaha untuk melakukan semua tugas dan menyelesaikan pekerjaannya di kantor dengan baik dan tidak dibawa pulang.

Lee dan Edmondson (2017)

menyebutkan beberapa teknik manajemen diri, yakni:

a. Standard-setting, menentukan sasaran, target tingkah laku atau prestasiyang hendak dicapai. Bila tujuan sudah 
ditetapkan, akan lebih mengarahkan seseorang pada bagaimana tujuan tersebut dapat dicapai, misalnya seorang wanita karir yang memiliki rencana dan tujuan yang mantap akan dapat mencapai kesuksesan dalam pekerjaannya;

b. Self monitoring, bentuk aplikasi dari teknik ini antara lain dengan caramencatat atau membuat grafik sehingga perubahan data dapat dilihat individu yang bersangkutan dan berfungsi sebagai insentif atau penguat (reinforcer), misalnya seorang karyawan memiliki sebuah catatan khusus yang digunakan untuk memantau perkembangan pekerjaannya, biasanya akan lebih cepat berkembang di bidangnya;

c. Self evaluation, dalam tahap ini, individu yang bersangkutan mengevaluasi kembali perkembangan rencana kerjanya, misalnya seorang karyawan mengevaluasi hasil kerjanya apakah sudah memenuhi target atau belum, karena bila belum, maka dia dapat memperbaiki diri agar targetnya dapat terpenuhi, misalnya urusan pengambilan keputusan menghambat pencapaian target pekerjaan, maka karyawan tersebut dapat berusaha menyesuaikan dan memperbaiki diri, seperti mencari cara yang menyelesaikan pekerjaan tepat pada waktunya tanpa terganggu pengambilan keputusannya; dan

d. Self reinforcement, teknik menghargai diri sendiri secara positif, seperti memberi penilaian atau penghargaan terhadap apa yang telah dilakukan, misalnya seorang karyawan melakukan penilaian atas hasil kerjanya dan cara pengambilan keputusannya, bila targetnya terpenuhi, maka dia dapat menghadiahi dirinya sendiri sebagai imbalan atas usaha yang telah dilakukan.
Lee dan Edmondson mengemukakan bahwa tingkat efektivitas individu dalam melakukan manajemen diri dipengaruhi oleh sejauh mana individu mampu mempertahankan (surviving), memelihara (maintaining), dan mengembangkan (developing) dirinya. Empat aspek diri yang harus dimiliki oleh seorang yang memiliki manajemen diri yang baik yaitu:

a. Kesehatan (health)

Kondisi fisik maupun psikis mempengaruhi seseorang dalam mengarahkan aktivitas kehidupannya. Kesehatan fisik menjadi modal utama untuk melakukan aktivitas, kesehatan psikis menciptakan kondisi mental yang stabil, misalnya wanita karir yang kondisi fisik dan mentalnya baik akan dapat mengerjakan dan menyelesaikan pekerjaan dan dapat mengambil keputusan dengan baik;

b. Keterampilan atau keahlian (skills) Keterampilan yang dimiliki menggambarkan kualitas individu. Individu dapat memutuskan untuk menjadi orang yang memiliki beberapa keahlian sekaligus ( $a$ multi-skilled person), misalnya seorang karyawan yang merangkap sebagai konsultan perkawinan, juru masak, pedagang atau ahli kecantikan. Individu tersebut menjadi orang yang memiliki satu keahlian di bidang tertentu dan memberi perhatian lebih untuk meningkatkan kemampuan yang dimilikinya (a spesialist), misalnya seorang karyawan yang memiliki keahlian khusus dalambidang perdagangan, maka dia dapat memanfaatkan dan meningkatkan keahliannya tersebut di waktu senggangnya di rumah;

c. Aktivitas (action)

Seberapa jauh individu mampu menyelesaikan aktivitas hidupnya 
dengan baik, contohnya mampu membuat keputusan dan mengambil inisiatif, misalnya karyawan mampu mengambil keputusan dengan cepat dan memiliki ide-ide cemerlang berkaitan dengan pekerjaan dan mampu mengambil keputusan dengan tepat; dan

d. Identitas diri (identity)

Seberapa jauh pengetahuan, pemahaman, dan penilaian individu terhadap dirinya akan mempengaruhi cara dia bertindak, misalnya karyawan yang tahu kelebihan dan kekurangan dirinya dengan baik akan dapat menentukan target pekerjaan yang akan dicapainya, tanpa harus memaksakan diri karena menginginkan hasil yang lebih baik, karena dia dapat menerapkan manajemen diri yang baik.

Dalam tulisan ini sedikitnya ada tujuh teknik atau strategi sederhana yang dapat diterapkan untuk melakukan manajeman diri, yaitu mendorong dan memotivasi diri, mengorganisasikan diri, mengendalikan diri, menetapkan standar yang berlaku, memonitor kerja, mengevaluasi kerja dan memberi penguat pada hasil kerjanya. Teknik tersebut harus didasari oleh kepribadian yang hangat, memiliki kecerdasan, keberanian, kestabilan emosi, ketajaman berpikir, rasa aman, pemenuhan kebutuhan diri dan disiplin diri sesuai dengan pendapat (Ding, 2016).

\section{Kematangan Emosi}

Banyak orang berpendapat, kesuksesan seseorang ditandai dengan berkembangnya prestasi serta kematangan emosinya. Meski tidak ada orang yang menyangkal pernyataan ini, tetapi sedikit orang yang mengetahui secara pasti tentang bagaimana penampilan seseorang yang dewasa atau matang itu, bagaimana cara berpakaian dan berdandannya, bagaimana caranya menghadapi tantangan, bagaimana tanggung jawabnya terhadap keluarga dan pekerjaan, danbagaimana pandangan hidupnya tentang dunia ini. Kematangan emosi adalah sebuah modal yang sangat berharga.

Kematangan emosi menurut Nicholl, Levy, dan Perry (2015) adalah suatu kondisi yang ditandai oleh perkembangan emosi dan pemunculan perilaku emosi yang tepat sesuai dengan usia dewasa daripada bertingkah laku seperti anak-anak. Jadi, semakin berkembang usia individu, maka diharapkan akan semakin mampu melihat segala sesuatunya secara objektif, mampu membedakan perasaan dan kenyataan, serta bertindak atas dasar fakta daripada perasaan. Dalam kamus yang berbeda, Somerville (2016) kematangan emosi didefinisikan sebagai suatu keadaan atau kondisi mencapai tingkat kedewasaan dari perkembangan emosi, dan karena itu individu yang bersangkutan tidak lagi menampilkan pola emosional yang pantas bagi anak-anak.

Lebih jauh Guhn, Gadermann, Almas, Schonert-Reichl, dan Hertzman (2016) mengemukakan bahwa kematangan emosi adalah kemampuan untuk mengekspresikan perasaan yang ada dalam diri secara yakin dan berani, yang diimbangi dengan pertimbanganpertimbangan akan perasaan dan keyakinan akan individu lain. Jadi, kematangan emosi adalah hal penting dalam pengembangan kapasitas positif dalam berhubungan dengan individu lain. Kematangan emosi tidak hanya memungkinkan seorang individu untuk berhubungan dengan individu lain secara dewasa, dalam arti individu dapat mengontrol dirinya sendiri dan dapat menikmati hubungan tersebut (Pant \& Valentina, 2014). Hal ini dikarenakan individu yang matang emosinya memiliki penghargaan pada individu lain.

Noorani dan Refahi (2015) menyatakan bahwa individu yang matang emosinya terbuka terhadap pengalaman, tidak berpurapura, dan percaya pada kapasitas dirinya untuk mengorganisasikan dan menginterpretasikan bahan pengalamannya. Hal ini berarti individu yang matang akan menggunakan bahan 
pengalamannya sebagai pengajaran dalam mengambil keputusan dan memandang kehidupannya sehari-hari. Individu yang matang emosinya dengan kata lain mampu memandang pengalaman hidup sebagai proses belajar. Pada saat pengalaman bersifat positif, individu akan menikmatinya dan merasa bahagia. Saat pengalaman negatif, ia akan mampu mempertanggungjawabkan dan merasa percaya diri bahwa dirinya mampu belajar dari kejadian ini untuk meningkatkan kualitas hidupnya. Pada saat keadaan tidak berjalan sebagaimana yang diinginkannya, maka individu akan mencari kesempatan agar berhasil.

Dalam tulisan ini pengertian kematangan emosi adalah kemampuan untuk melihat segala sesuatunya secara objektif, mampu membedakan perasaan dan kenyataan, bertindak atas dasar fakta daripada perasaan, mampu mengekspresikan perasaan yang ada dalam diri secara yakin dan berani, yang diimbangi dengan pertimbangan-pertimbangan akan perasaan dan keyakinan akan individu lain, memiliki penghargaan pada individu lain, memandang pengalaman hidup sebagai proses belajar dan mampu mempertanggungjawabkan perbuatannya.

\section{Model Penelitian}

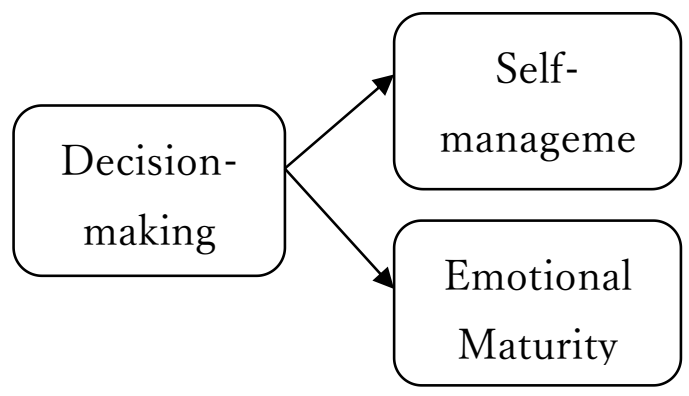

Gambar 1. Model teoritis hubungan antar variabel

\section{Proposisi Penelitian}

Hasil penelitian ini dalam bentuk proposisi. Setiap karyawan pasti mengharapkan kesuksesan dan kelancaran dalam bekerja. Kepercayaan rekan kerja dan atasan sedikit banyak dapat menaikkan popularitas mereka di tempat kerja. Ada hal yang tak kalah penting, yaitu ketepatan mereka dalam mengambil keputusan, terutama keputusan-keputusan yang berkaitan dengan kelangsungan pekerjaan mereka. Saat seorang karyawan mampu mengambil keputusan yang tepat di tempat kerja, ia akan mendapat perhatian dari rekan kerja dan atasannya. Bila mereka melakukan kesalahandalam mengambil keputusan maka banyak pandangan negatif yang akan tertuju padanya.

Menurut Xu (2015), seorang karyawan memiliki peran penting yang berkaitan dengan pengelolaan informasi dan pengambilan keputusan, serta tuntutan untuk menjadi komunikator dan membina relasi dengan pihak internal perusahaan, serta pihak eksternal perusahaan dalam lingkup global membutuhkan kapasitas intelektual yang memadai, kemampuan manajemen diri yang handal, kematangan emosi dan sikap yang tepat, serta kemampuan untuk menampilkan citra profesional. Dalam era informasi, kemajuan perusahaan sangat ditentukan oleh kemampuan karyawannya untuk memperoleh dan memproses informasi agar dapat mengambil keputusan yang cepat dan akurat (Manning \& DiLollo, 2018). Kemampuan karyawan terutama yang menduduki level manajer ke atas, dalam mengambil keputusan adalah aset penting bagi perusahaan. Tak jarang kelangsungan hidup perusahaan justru tergantung pada tepat tidaknya keputusan yang diambil oleh para manajer dan pimpinannya.

\section{Proposisi 1:}

Pengambilan keputusan berpengaruh terhadap manajemen diri

Pengambilan keputusan yang baik dapat dipelajari. Banyak hal yang dapat mempengaruhi sebuah keputusan yang baik antara lain adalah kemempuan manajemen diri yang baik dan kematangan emosi seseorang. Menindaklanjuti hal tersebut, beberapa ahli mengatakan tentang faktor-faktor yang dapat 
mempengaruhi pengambilan keputusan antara lain adalah kematangan emosi, kepribadian, intuisi, umur, pendidikan formal, pengalaman karir, kreativitas dan kemampuan personal (Newell \& Shanks, 2014; Rezaei, 2015; Newell, Lagnado, \& Shanks, 2015). Di antara semuanya, kemampuan personal dan sikap manajer sebagai pengambilkeputusan dianggap sebagai faktor terpenting untuk dapat mengambil keputusan yang tepat. Seberapapun besarnya kemampuan seorang manajer dalam membuat keputusan dan bertanggung jawab, ia memerlukan kemampuan agar menghasilkan keputusan yang tepat. Kemampuan ini banyak dipengaruhi oleh pengalaman, tingkat pemahaman pada situasi yang dihadapi dan kualitas manajemen diri individu.

Orang yang dewasa secara emosi, meski harus dengan sabar mengumpulkan fakta untuk memecahkan persoalan, dapat mengambil keputusan berdasarkan data-data yang kurang lengkap. Dia sadar bahwa terkadang dia harus mengambil tindakan berdasarkan keyakinan terhadap dirinya sendiri. Dia bersedia memikul resiko, namun tetap berdasarkan perkiraan-perkiraan yang terbaik yang dapat diperolehnya. Dia tahu, jika harus menunggu semua kepastian, mungkin sekali dia akan ketinggalan kapal (Francis, Hasan, Park, \& Wu, 2015).

Pengambilan keputusan merupakan tugas yang cukup berat, jika tidak didorong kematangan emosi dan manajemen diri yang baik maka seseorang akan sulit mengambil suatu keputusan. Banyak karyawan yang terjebak dan salah langkah dalam mengambil keputusan karena hanya mementingkan emosi sesaat sehingga mereka melupakan langkahlangkah penting yang seharusnya dilakukan dan prosedur yang seharusnya dilewati. Kematangan emosi dan kemampuan manajemendiri yang baik akan membawa seseorang ke arah rasa percaya diri yang mantap, sehingga proses dan tahapan dalam pengambilan keputusan dapat dilakukan secara maksimal.

\section{Proposisi 2:}

Pengambilan keputusan berpengaruh pada kematangan emosi.

Orang yang dewasa secara emosi, meski harus dengan sabar mengumpulkan fakta untuk memecahkan persoalan, dapat mengambil keputusan berdasarkan data-data yang kurang lengkap. Dia sadar bahwa terkadang dia harus mengambil tindakan berdasarkan keyakinan terhadap dirinya sendiri. Dia bersedia memikul resiko, namun tetap berdasarkan perkiraan-perkiraan yang terbaik yang dapat diperolehnya. Dia tahu, jika harus menunggu semua kepastian, mungkin sekali dia akan ketinggalan kapal (Zhao \& Smillie, 2014).

Pengambilan keputusan merupakan tugas yang cukup berat, jika tidak didorong kematangan emosi dan manajemen diri yang baik maka seseorang akan sulit mengambil suatu keputusan. Banyak karyawan yang terjebak dan salah langkah dalam mengambil keputusan karena hanya mementingkan emosi sesaat sehingga mereka melupakan langkahlangkah penting yang seharusnya dilakukan dan prosedur yang seharusnya dilewati. Kematangan emosi dan kemampuan manajemendiri yang baik akan membawa seseorang ke arah rasa percaya diri yang mantap, sehingga proses dan tahapan dalam

Pengambilan keputusan dapat dilakukan secara maksimal.Untuk menjelaskan hubungan ketiga variabel dalam penelitian ini, makaperlu disederhanakan dalam gambar seperti di bawah ini: 


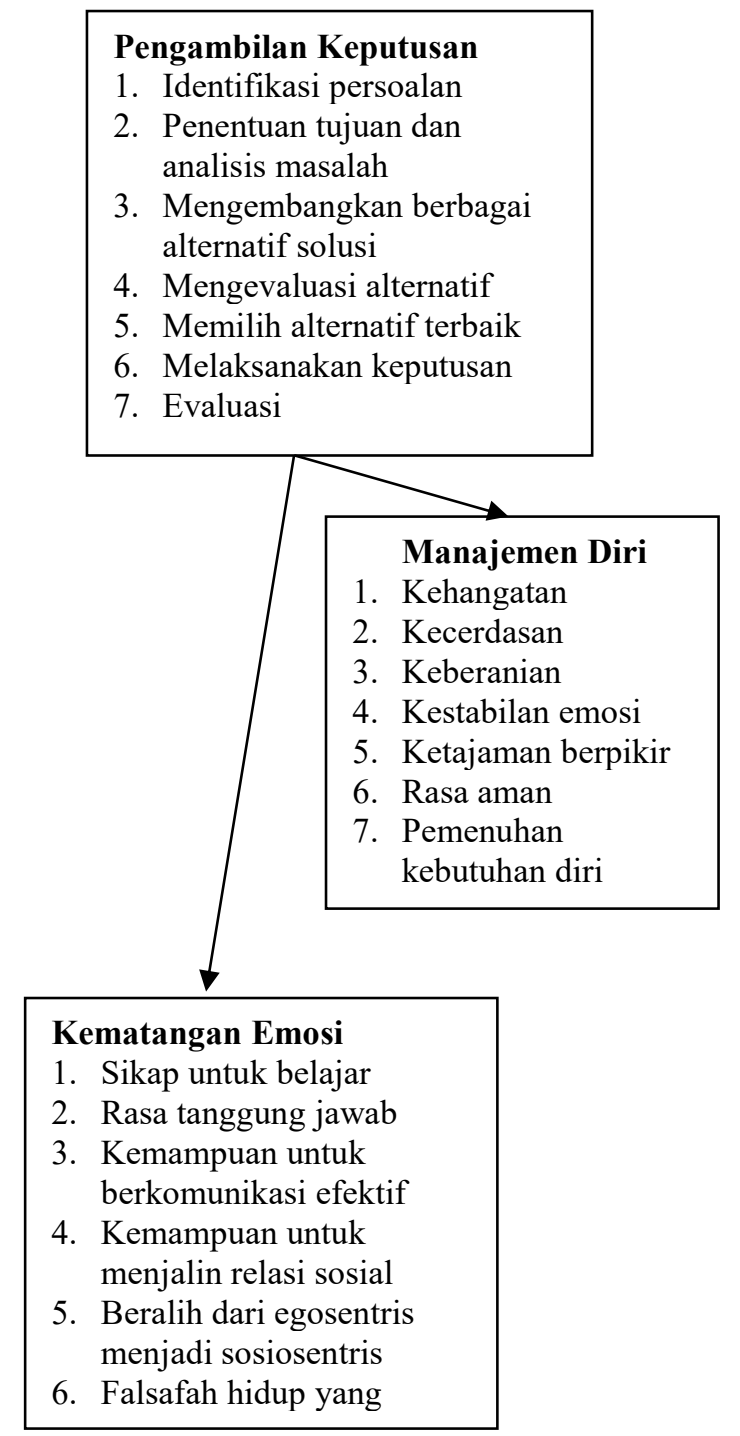

Hasil penelusuran pada kajian pustaka menunjukkan ada hubungan positif antara manajemen diri dan kematangan emosi dengan pengambilan keputusan. Hal tersebut sejalan dengan pendapat Costa, Vives, dan Corey (2017), yang mengemukakan bahwa selain kematangan emosi, masih banyak faktor lain yang mempengaruh orientasi pengambilan keputusan antara lain adalah kepribadian, intuisi, umur, pendidikan formal dan pengalaman karir. Sedangkan Rocklage dan Fazio (2016) dalam penelitiannya menemukan bahwa suasana hati yang positif dapat meningkatkan kecepatan dan efisiensi pengambilan keputusan. Sedangkan menurut Li, Ashkanasy, dan Ahlstrom (2014) dalam penelitiannya membuktikan bahwa motivasi memainkan peranan penting dalam pengambilan keputusan. Selain itu, menurut Simpson, Clegg, dan Pitsis (2014) pengambilan keputusan dapat dipermudah atau dihambat oleh adanya efikasi diri. Johnson, Schamuhn, Nelson, dan Jr. (2014) mengemukakan pula bahwa orientasi pengambilan keputusan juga dapat dipengaruhi oleh faktor dari dalam dan luar diri individu. Faktor luar yang juga berpengaruh antara lain, jenis keputusan yang diambil (rutin dan tidak rutin), waktu yang tersedia, besarnya resiko yang harus ditanggung, tingkat penerimaan dan dukungan oleh rekan dan atasan, pendidikan formal, dan pengalaman karir seseorang. Namun berdasarkan hasil perhitungan, dapat dikatakan bahwa hipotesis yang diajukan dalam penelitian ini diterima. Artinya terdapat hubungan positif antara manajemen diri dan kematangan emosi dengan orientasi pengambilan keputusan. Semakin tinggi kemampuan manajemen diri dan kematangan emosi yang dimiliki seorang, maka makin efektif pula pengambilan keputusan yang dilakukan.

Sebelum melakukan pengambilan keputusan, terlebih dulu dilakukan pengidentifikasian persoalan. Proses pangambilan keputusan umumnya dimulai 
setelah permasalahan diidentifikasi. aitem kestabilan emosi, yang Kemudian, setelah masalah diidentifikasi, menitikberatkan pada konsentrasi dan tidak tujuan dapat diformulasikan. Faktor mudah kawatir.

manajemen diri yang mempengaruhi proses pengidentifikasian persoalan adalah faktor kecerdasan, seseorang. Kecerdasan yang dimaksud bukan hanya terbatas pada kemampuan menyelesaikan persoalan akademis tetapi juga kemampuan dalam menyelesaikan masalah sosial, misalnya karyawan akan dapat menyelesaikan permasalahan yang dihadapi dalam pekerjaan, kreatif, dan berwawasan luas. Diperlukan suatu kecerdasan agar dapat mengidentifikasi masalah dengan tepat. Faktor berikutnya adalah disiplin diri. Individu yang memiliki disiplin diri yang tinggi biasanya dapat mengontrol diri, misalnya karyawan dapat mengontrol atau mengatur waktu dan kegiatannya salah satunya adalah memiliki jadwal harian yang selalu ditaatinya. Dengan adanya kontrol yang baik pada dirinya, individu tidak akan menyia-nyiakan waktu dalam mengidentifikasi persoalan, efisiensi waktu dalam mengidentifikasi persoalan secara tidak langsung akan mempercepat proses orientasi pengambilan keputusan.

Tahap berikutnya setelah mengidentifikasi persoalan, hal yang dilakukan selanjutnya adalah menentukan tujuan dan analisis masalah. Analisis masalah, penetapan tujuan dan sasaran secara memadai akan menentukan hasil yang akan dicapai. Faktor manajemen diri yang berpengaruh pada proses ini adalah kestabilan emosi. Orang dengan kestabilan emosi yang tinggi jarang mengalami kecemasan, emosinya tidak mudah meledak, dan sabar. Hal-hal tersebut sangat diperlukan dalam penentuan tujuan dan analisis masalah. Kecemasan atau ketidaksabaran dapat mengakibatkan kesalahan dalam penentuantujuan dan analisis masalah. Hal tersebut didukung oleh $\begin{array}{ccc}\text { Langkah } & \text { selanjutnya } & \text { dalam } \\ \text { pengambilan } & \text { keputusan } & \text { adalah }\end{array}$ pengembangan alternatif solusi. Sebelum mengambil keputusan, harus dikembangkan beberapa alternatif solusi yang dapat dilaksanakan dan harus dipertimbangkan konsekwensinya yang mungkin terjadi dari tiap-tiap alternatif tersebut. Faktor manajemen diri yang berpengaruh adalah disiplin diri. Orang yang mampu mendisiplinkan dirinya, akan dapat mengontrol perilakunya. Dapat memilih solusi apa yang sesuai berikut konsekwensinya, dan tidak membuang waktu hanya untuk memikirkan alternatif yang kurang bermanfaat.

Alternatif solusi telah dikembangkan, langkah selanjutnya adalah mengevaluasi alternatif yang ada. Faktor manajemen diri yang mempengaruhi evaluasi alternatif ini adalah rasa aman. Rasa aman membuat orang tidak mudah putus asa menghadapi masalah yang muncul, percaya diri, dan mampu menghargai dirinya sendiri. Hal ini sangat dibutuhkan dalam mengevaluasi berbagai alternatif solusi yang muncul. Individu tidak mudah putus asa dan tetap percaya diri, walaupun suatu saat evaluasi yang diambilnya saat itu ternyata kurang sesuai.

Tahapan berikutnya individu kemudian memilih alternatif yang terbaik. Tujuan memilih alternatif adalah memecahkan persoalan agar dapat mencapai tujuan dan sasaran yang telah ditentukan. Faktor manajemen diri yang berhubungan positif dengan pemilihan alternatif terbaik adalah kestabilan emosi. Individu yang emosinya stabil, jarang mengalami kecemasan dan kekhawatiran. Hal ini sangat menentukan pemilihan suatu alternatif terbaik. Saat 
diharuskan memilih sebuah alternatif, individu diharapkan mampu berkonsentrasi agar alternatif yang dipilihnya merupakan pilihan yang terbaik. Karena tidak ada kecemasan dan kekhawatiran yang mengiringi proses pemilihan itu.

Akhirnya, setelah alternatif terbaik dipilih, tibalah saat bagi individu untuk melaksanakan keputusan yang telah diambilnya. Pelaksanakan keputusan hendaknya dilakukan secara efektif untuk mencapai sasaran yang telah ditetapkan. Faktor manajemen diri yang memiliki pengaruh positif bagi pelaksanaan keputusan adalah kecerdasan. Kecerdasan ini tidak hanya cerdas secara akademis, namun juga cerdas dalam lingkungan sosial. Dalam pelaksaan keputusan, kadang kala individu berhubungan dengan orang lain. Individu harus kreatif membaca situasi agar pelaksanaan keputusan yang diambil tidak merugikan orang lain, namun tetap dapat membawa hasil yang optimal.

Langkah terakhir yang harus dilakukan dalan pengambilan keputusan adalah mengevaluasi keputusan yang telah diambil. Evaluasi perlu dilakukan agar apa yang diharapkan dari keputusan tersebut dapat terealisir. Evaluasi didasarkan atas sasaran dan tujuan yang telah ditetapkan. Faktor manajemen diri yang memiliki hubungan positif dengan evaluasi adalah kecerdasan. Diperlukan kecerdasan dan kreativitas untuk menganalisa keputusan yang telah diambil. Rappaport dan Corbally (2016) mengatakan bahwa salah satu faktor yang mempengaruhicara seseorang dalam mengambil keputusan adalah kreativitas. Ide kreatif akan memuncukkan keputusan yang kreatif pula. Hasil dari keputusan-keputusan yang kreatif akan membantu dalam memberikan kontribusi bagi perbaikan produktivitas organisasi dan berperan dalam penelitian produk baru. Faktor lain yang juga berhubungan dengan evaluasi adalah disiplin diri. Individu yang disiplin biasanya dapat mengontrol diri, mengatur waktu dan kegiatannya. Individu yang disiplin akan mematuhi aturan dan jadwal yang telah dibuatnya. Apabila hasil evaluasi tidak sesuai dengan yang direncanakan, dia akan segera berpikir ulang untuk memperbaikinya agar sesuai dengan target yang diinginkannya. Oleh karena itu, faktor kecerdasan dan disiplin diri saling berkaitan dalam evaluasi akhir ini.

Selain faktor-faktor manajemen diri, beberapa faktor-faktor kematangan emosi juga memiliki hubungan positif dengan faktor-faktor orientasi pengambilan keputusan. Namun ternyata tidak satupun faktor-faktor Kematangan emosi yang berhubungan secara signifikan dengan faktor identifikasi persoalan, penentuan tujuan dan analisis masalah, evaluasi alternatif, dan pemilihan alternatif. Faktor kematangan emosi hanya memiliki pengaruh positif terhadap faktor pengembangan alternatif, pelaksanaan keputusan, dan evaluasi total.

Langkah pertama yang harus dilakukan dalam orientasi pengambilan keputusan adalah identifikasi persoalan. Sebuah syarat yang perlu bagi keputusan adalah persoalan. Proses pangambilan keputusan umumnya dimulai setelah permasalahan diidentifikasi. Setelah masalah diidentifikasi, tujuan dapat diformulasikan. Ternyata hasil yang diperoleh dari penelitian ini, tidak adasatupun faktor kematangan emosi yang mempengaruhi proses identifikasi persoalan secara signifikan. Hal tersebut karena identifikasi persoalan kemampuan untuk mau belajar, bertanggung jawab, dapat berkomunikasi dengan baik, mampu melakukan hubungan sosial yang baik, beralih dari egosentrisme kematangan emosi 
sosiosetrisme ataupun falsafah hidup yang terintegrasi tidak terlalu berperan, jika berperanpun hanya sedikit sekali hingga bisa diabaikan. Hal tersebut dapat dicermati pada aitem-aitem keenam faktor di atas, selain itu dalam identifikasi persoalan yang dilakukan adalah memilah dan menentukan apa dan bagaimana masalah yang sebenarnya dihadapi. Hal tersebut dapat dicermati pada aitem identifikasi persoalan.

Hal yang dilakukan berikutnya adalah menentukan tujuan dan analisis masalah. Analisis masalah, penetapan tujuan dan sasaran secara memadai akan menentukan hasil yang akan dicapai. Sekali lagi, tidak ada satupun faktor dari kematangan emosi yang memiliki pengaruh yang signifikan terhadap orientasi pengambilan keputusan. Keenam faktor tersebut tidak terlalu berperan, jika berperanpun hanya sedikit sekali hingga bisa diabaikan. Hal ini dapat dilihat dari aitemaitem keenam faktor di atas, selain itu dalam proses ini, individu menentukan target dan tujuan yang hendak dicapai, dan menganalisis masalah yang sebenarnya terjadi berdasarkan informasi yang telah diperoleh dari proses identifikasi masalah. Hal tersebut dapat dilihat pada aitem penentuan tujuan dan analisis masalah.

Langkah selanjutnya adalah mengembangkan berbagai alternatif solusi. Sebelum mengambil keputusan, harus dikembangkan beberapa alternatif solusiyang dapat dilaksanakan dan harus dipertimbangkan konsekwensi yang mungkin terjadi dari tiap-tiap alternatif tersebut. Faktor kematangan emosi yang berpengaruh positif adalah falsafah hidup yang terintegrasi. Individu yang falsafah hidupnya terintegrasi dangan baik memiliki cara berpikir yang matang dan bersifat menyeluruh, yaitu memperhatikan fakta-fakta tertentu secara tersendiri dan menggabungkannya untuk melihat arti keseluruhan yang muncul. Dengan falsafah hidup yang terintegrasi, pengembangan alternatif solusi dibuat dengan berbagai pertimbangan, didasarkan pada penilaian yang objektif dan terlepas dari prasangka.

Langkah selanjutnya setelah mengembangkan alternatif solusi adalah mengevaluasi alternatif yang ada. Dalam proses ini, alternatif yang ada kemudian harus dievaluasi dan dibandingkan. Untuk selanjutnya dipilih yang terbaik. Proses evaluasi alternatif ini, juga tidak dipengaruhi secara signifikan oleh faktor-faktor kematangan emosi. Karena sikap mau belajar, bertanggung jawab, berkomunikasi dan menjalin hubungan sosial yang baik, tidak perlu pula mengubah pandangan dari egosentrisme kematangan emosi sosiosentrisme, ataupun memiliki falsafah hidup yang terintegrasi dalam kegiatan evaluasi alternatif tidak berperan secara signifikan pada proses pengembangan alternatif solusi, jika berperanpun sangat kecil sekali sehingga dapat diabaikan. Hal tersebut tercermin pada aitem aitem keenam faktor di atas.kemudian diperbandingkan dengan aitem-aitem pengembangan alternatif solusi.

Tahap berikutnya individu kemudian memilih alternatif terbaik. Tujuan memilih alternatif yang terbaik adalah memecahkan persoalan agar dapatmencapai tujuan dan sasaran yang telah ditentukan. Ternyata tidak ada satupun faktor kematangan emosi yang terlibat secara signifikan dalam proses pemilihan alternatif ini. Jika terlibatpun, peranannya kecil sekali, hingga dapat diabaikan. Hal tersebut dapat dilihat pada aitem keenam faktor di atas, selain itu pemilihan alternatif terbaik hanya melibatkan diri individu sendiri, dan belum melibatkan interaksi dengan orang lain. Pernyataan ini 
didukung oleh aitem pemilihan alternatif terbaik.

Langkah berikutnya setelah salah satu alternatif yang terbaik dipilih adalah melaksanakan keputusan. Pelaksanaan keputusan hendaknya dilakukan secara efektif untuk mencapai sasaran yang telah ditetapkan. Faktor kematangan emosi yang memiliki pengaruh positif terhadap pelaksanaan keputusan adalah kemampuan untuk menjalin hubungan sosial. Individu yang mampu menjalin hubungan sosial yang baik akan melihat kebutuhan individu lain dan memberikan potensi dirinya untuk dibagikan pada individu lain yang membutuhkan. Dalam arti, individu yang memiliki hubungan sosial yang baik, akan memperhatikan pula kepentingan orang lain selain kepentingannya sendiri. Dia ingin agar keputusan yang diambilnya dapat berguna untuk orang lain pula.

Akhirnya, setelah semua tahap di atas terpenuhi, tibalah saat bagi individu untuk mengevaluasi semua tindakan yang telah dilakukan sebelumnya. Evaluasi didasarkan atas sasaran dan tujuan yang telah ditetapkan. Evaluasi dilakukan dengan tujuan untuk melihat apakah hasil yang dicapai sudah sesuai dengan yang diharapkan atau belum. Faktor manajemen diri yang memiliki pengaruh positif terhadap mekanisme evaluasi adalah kemampuan untuk menjalin hubungan sosial. Individu yang mampu berkomunikasi dengan baik dapat melihat kebutuhan individu lain dan memberikan potensi dirinya dalam bentuk uang, waktu atau tenaga untuk dibagikan pada individu lain yang membutuhkan. Oleh karena itu, melalui evaluasi terhadap keputusan yang diambilnya, diharapkan dia dapat menentukan apakah keputusan yang ambilnya juga dapat bermanfaat bagi orang lain atau tidak.
Dari pengujian hubungan tiap faktor kematangan emosi terhadap tiap faktor orientasi pengambilan keputusan didapatkan bahwa secara keseluruhan memang kematangan emosi berhubungan positif dengan orientasi pengambilan keputusan. Berdasarkan penelitian lebih lanjut ternyata tidak semua faktor kematangan emosi berhubungan secara signifikan dengan faktor pengambilan keputusan. Karena perhitungan perfaktor ini lebih teliti dari hubungan secara keseluruhan.

\section{Simpulan}

Hasil kajian ini menunjukkan bahwa seluruh faktor manajemen diri dapat digunakan untuk memprediksikan orientasi pengambilan keputusan, namun tidak faktor kematangan emosi dapat digunakan untuk memprediksi orientasi pengambilan keputusan. Seluruh faktor manajemen diri dapat digunakan untuk memprediksi pengambilan keputusan. Hal tersebut bertentangan dengan factorkematangan emosi, karena hanya beberapa faktor kematangan emosi yang dapat digunakan untuk memperdiksi pengambilan keputusan, karena dalam kematangan emosi hanya faktor falsafah hidup dan kemampuan menjalin hubungan sosial yang memiliki hubungan positif dengan faktor-faktor pengambilan keputusan.

Kemampuan manajemen diri dan kematangan emosi merupakan aspek psikologis yang dapat mempengaruhi orientasi pengambilan keputusan. Secara praktis, setelah diketahuinya beberapa faktor yang turut mempengaruhi kemampuan manajemen diri dan kematangan emosi yang dapat mempengaruhi orientasi pengambilan keputusan karyawan, pihak manajemen perusahaan dapat melakukan upaya-upaya untuk meningkatkan kemampuan manajemen 
diri dan kematangan emosi karyawan sehingga keputusan yang diambil dapat lebih bermanfaat bagi perusahaan. Salah satu caranya misalnya dengan pelatihan-pelatihan untuk meningkatkan kemampuan manajemen diri, dan kematangan emosi karyawan. Selanjutnya, alat ukur ini juga dapat digunakan dalam proses seleksi dan penempatan karyawan, sehingga calon yang didapat sesuai dengan yang dibutuhkan. Selain itu, juga dapat digunakan dalam proses performanceappraisal. Dilakukannya beberapa hal tersebut diharapkan dapat meningkatkankemampuan pengambilan keputusan, sehingga tujuan-tujuan perusahaan dapat dicapai.

\section{Referensi}

Anderson, D. L. (2017). Organization Development; The Process of Leading Oraginizational Change (4 ed.). Los Angeles: Sage Publications Ltd.

Beach, L. R. (2014). Decision Making in the Workplace; A Unified Perspective. New York: Psychology Press.

Betsch, T. (2014). Preference Theory: An Affect-Based Approach to Recurrent Decision Making. Dalam T. Betsch, \& S. Haberstroh, The Routines of Decision Making (hal. 58-72). New York: Psychology Press.

Birkland, T. A. (2016). An Introduction to the Policy Process; Theories, Concepts, and Models of Public Policy Making (4 ed.). New York: Routledge.
Breevaart, K., Bakker, A. B., \& Demerouti, E. (2014). Daily self-management and employee work engagement. Journal of Vocational Behavior, 84(1), 31-38. doi:https://doi.org/10.1016/j.jvb.2013. 11.002

Brown, A. D., Colville, I., \& Pye, A. (2014). Making Sense of Sensemaking in Organization Studies. Organization Studies, $\quad 36(2), \quad 265-277$. doi:https://doi.org/10.1177/01708406 14559259

Chiu, C.-M., Liang, T.-P., \& Turban, E. (2014). What can crowdsourcing do for decision support? Decision Support Systems, 65, 40-49. doi:https://doi.org/10.1016/j.dss.2014. 05.010

Collier, P. M. (2015). Accounting for Managers (5 ed.). UK: John Wiley \& Sons Ltd.

Costa, A., Vives, M.-L., \& Corey, J. D. (2017). On Language Processing Shaping Decision Making. Current Directions in Psychological Science, 26(2), 146-151. doi:https://doi.org/10.1177/09637214 16680263

Cummings, T. G., \& Worley, C. G. (2015). Organization Development \& Change. Stamford: Cengage Learning.

Davenport, T. H. (2015). Process Management for Knowledge Work. 
Dalam J. v. Brocke, \& M. Rosemann, Handbook on Business Process Management 1. International Handbooks on Information Systems (hal. 17-35). Berlin, Heidelberg: Springer. doi:https://doi.org/10.1007/978-3642-45100-3 2

Ding, J. (2016). Advances in Network Management. New York: Auerbach Publications.

Dror, Y. (2017). Public Policy Making Reexamined (1 ed.). New York: Routledge. doi:https://doi.org/10.4324/97813151 27774

Francis, B., Hasan, I., Park, J. C., \& Wu, Q. (2015). Gender Differences in Financial Reporting Decision Making: Evidence from Accounting Conservatism. Contemporary Accounting Research, 32(3), 12851318 doi:https://doi.org/10.1111/19113846.12098

Gerston, L. N. (2014). Public Policy Making; Process and Principles. New York: Routledge.

Gorman, G. E., \& Pauleen, D. J. (2016). The Nature and Value of Personal Knowledge Management. Dalam D. J. Pauleen, Personal Knowledge Management; Individual, Organizational and Social
Perspectives (hal. 1-16). London: Routledge.

Govindan, K., Rajendran, S., Sarkis, J., \& Murugesan, P. (2015). Multi criteria decision making approaches for green supplier evaluation and selection: a literature review. Journal of Cleaner Production, 98, 66-83. doi:https://doi.org/10.1016/j.jclepro.2 013.06.046

Graham, J. R., Harvey, C. R., \& Puri, M. (2015). Capital allocation and delegation of decision-making authority within firms. Journal of Financial Economics, 115(3), 449470.

doi:https://doi.org/10.1016/j.jfineco.2 014.10 .011

Guhn, M., Gadermann, A. M., Almas, A., Schonert-Reichl, K. A., \& Hertzman, C. (2016). Associations of teacherrated social, emotional, and cognitive development in kindergarten to selfreported wellbeing, peer relations, and academic test scores in middle childhood. Early Childhood Research Quarterly, 35, 76-84. doi:https://doi.org/10.1016/j.ecresq.20 15.12.027

Janssen, M., Voort, H. d., \& Wahyudi, A. (2017). Factors influencing big data decision-making quality. Journal of Business Research, 70, 338-345. doi:https://doi.org/10.1016/j.jbusres.2 016.08.007 
Johnson, P., Schamuhn, T. D., Nelson, D. B., \& Jr., W. C. (2014). Differentiation Levels of College Students: Effects on Vocational Identity and Career Decision Making. The Career Development Quarterly, 62(1), 70-80. doi:https://doi.org/10.1002/j.21610045.2014.00071.x

Kocet, M. M., \& Herlihy, B. J. (2014). Addressing Value-Based Conflicts Within the Counseling Relationship: A Decision-Making Model. Journal of Counseling \& Development, 92(2), 180-186.

doi:https://doi.org/10.1002/j.15566676.2014.00146.x

Kostera, M. (2014). Occupy Management; Inspirations and Ideas for SelfOrganization and Self-Management. London: Routledge.

Lee, M. Y., \& Edmondson, A. C. (2017). Self-managing organizations: Exploring the limits of lesshierarchical organizing. Research in Organizational Behavior, 37, 35-58. doi:https://doi.org/10.1016/j.riob.201 7.10 .002

Lee, M. Y., \& Edmondson, A. C. (2017). Self-managing organizations: Exploring the limits of lesshierarchical organizing. Research in Organizational Behavior, 37, 35-58. doi:https://doi.org/10.1016/j.riob.201 7.10 .002
Li, Y., Ashkanasy, N. M., \& Ahlstrom, D. (2014). The rationality of emotions: A hybrid process model of decisionmaking under uncertainty. Asia Pacific Journal of Management, 31(1), 293-308. doi:https://doi.org/10.1007/s10490012-9341-5

Linstead, S., Marechal, G., \& Griffin, R. W. (2014). Theorizing and Researching the Dark Side of Organization. Organization Studies, 35(2), 165-188. doi:https://doi.org/10.1177/01708406 13515402

Luhmann, N., Baecker, D., \& Barrett, R. (2018). Organization and Decision. UK: Cambrigde University Press.

Manning, W. H., \& DiLollo, A. (2018). Clinical Decision Making in Fluency Disorder. San Dioego, CA: Plural Publishing Inc.

Mardani, A., Jusoh, A., Nor, K. M., Khalifah, Z., Zakwan, N., \& Valipour, A. (2015). Multiple criteria decisionmaking techniques and their applications - a review of the literature from 2000 to 2014. Economic Research, 28(1), 516-571. doi:https://doi.org/10.1080/1331677X. 2015.1075139

Marinescu, D. C. (2017). Complex System and Clouds; A Self-Oragnization and Self-Management Perspective. London: Elsevier Inc. 
Maxwell, N. L., Rotz, D., \& Garcia, C. (2016). Data and Decision Making: Same Organization, Different Perceptions; Different Organizations, Different Perceptions. American Journal of Evaluation, 37(4), 463-485. doi:https://doi.org/10.1177/10982140 15623634

Mládková, L. (2015). Knowledge Workers and the Principle of 3S (SelfManagement, Self-organization, Selfcontrol). Social and Behavioral Sciences, $\quad 181, \quad 178-184$. doi:https://doi.org/10.1016/j.sbspro.2 015.04 .879

Monghasemi, S., Nikoo, M. R., Fasaee, M. A., \& Adamowski, J. (2015). A novel multi criteria decision making model for optimizing time-cost-quality trade-off problems in construction projects. Expert Systems with Applications, 42(6), 3089-3104. doi:https://doi.org/10.1016/j.eswa.201 4.11.032

Newell, B. R., \& Shanks, D. R. (2014). Unconscious influences on decision making: A critical review. Behavioral and Brain Sciences, 37(1), 1-19. doi:https://doi.org/10.10107/S014052 $5 \times 12003214$

Newell, B. R., Lagnado, D. A., \& Shanks, D. R. (2015). Straight Choices; The Psychology of Decision Making (2 ed.). London: Psychology Press.
Nicholl, A. R., Levy, A. R., \& Perry, J. L. (2015). Emotional maturity, dispositional coping, and coping effectiveness among adolescent athletes. Psychology of Sport and Exercise, 17, 32-39. doi:https://doi.org/10.1016/j.psychspo rt.2014.11.004

Noorani, M., \& Refahi, Z. (2015). A comparison of the spouse selection criteria and emotional. Social and Behavioral Sciences, 174, 2234-2239.

Pant, R. S., \& Valentina, L. (2014). Impact Analysis: Family Structure on Social and Emotional Maturity of Adolescents. The Anthropologist, 17(2), 359-365. doi:https://doi.org/10.1080/09720073. 2014.11891445

Pettigrew, A. M. (2009). The politics of organizational decision-making. UK: Routledge.

Putnam, L. L., Fairhurst, G. T., \& Banghart, S. (2016). Contradictions, Dialectics, and Paradoxes in Organizations: A Constitutive Approach. The Academy of Management Annals, 10(1), 65-171. doi:https://doi.org/10.1080/19416520. 2016.1162421

Rappaport, M. B., \& Corbally, C. (2016). The Emotional Brain Hypothesis: Emotional, Social, and Religious Vetting in the Evolution of Rational Decision Making and Scientific 
Modeling. Issues in Science and Theology, 42(3), 133-142. doi:https://doi.org/10.1007/978-3319-26769-2_10

Rezaei, J. (2015). Best-worst multi-criteria decision-making method. Omega, 53, 49-57.

doi:https://doi.org/10.1016/j.omega.2

014.11 .009

Rezaei, J. (2016). Best-worst multi-criteria decision-making method: Some properties and a linear model. Omega, 64, 126-130. doi:https://doi.org/10.1016/j.omega.2 015.12 .001

Rocklage, M. D., \& Fazio, R. H. (2016). On the Dominance of Attitude Emotionality. Personality and Social Psychology Bulletin, 42(2), 259-270. doi:https://doi.org/10.1177/01461672 15623273

Romiszowski, A. J. (2016). Designing Instructional Systems; Decision Making in Course Planning and Curriculum Design. London: Routledge.

Shaik, M. N., \& Abdul-Kader, W. (2014). Comprehensive performance measurement and causal-effect decision making model for reverse logistics enterprise. Computers \& Industrial Engineering, 68, 87-103. doi:https://doi.org/10.1016/j.cie.2013. 12.008
Sharma, R., Mithas, S., \& Kankanhalli, A. (2014). Transforming decisionmaking processes: a research agenda for understanding the impact of business analytics on organisations. European Journal of Information System, 23(4), 433-441. doi:https://doi.org/10.1057/ejis.2014. 17

Shepherd, D. A., Williams, T. A., \& Patzelt, H. (2014). Thinking About Entrepreneurial Decision Making: Review and Research Agenda. Journal of Management, 41(1), 11-46. doi:https://doi.org/10.1177/01492063 14541153

Shepherd, N. G., \& Rudd, J. M. (2014). The Influence of Context on the Strategic Decision-Making Process: A Review of the Literature. International Journal of Management Reviews, 16(3), 340-364. doi:https://doi.org/10.1111/ijmr.1202 3

Simpson, A. V., Clegg, S., \& Pitsis, T. (2014). Normal Compassion: A Framework for Compassionate Decision Making. Journal of Business Ethics, 119(4), 473-491.

doi:https://doi.org/10.1007/s10551013-1831-y

Smith, W. K. (2014). Dynamic Decision Making: A Model of Senior Leaders Managing Strategic Paradoxes. 
41 Jurnal Al-Qalb, Jilid 10, Nomor 1, Maret 2019, hlm. 20-41

Academy of Management Journal, 57(6), 428-438. doi:https://doi.org/10.5465/amj.2011. 0932

Snyder, G. H., \& Diesing, P. (1997). Conflict among Nation; Bargaining, Decision Making, and System Structure in International Crises. New Jersey: Princeton University Press.

Somerville, L. H. (2016). Searching for Signatures of Brain Maturity: What Are We Searching For? Neuron, 92(6), 1164-1167. doi:https://doi.org/10.1016/j.neuron.2 016.10.059

Tjader, Y., May, J. H., Shang, J., Vargas, L. G., \& Gao, N. (2014). Firm-level outsourcing decision making: A balanced scorecard-based analytic network process model. International Journal of Production Economics, 147 , 614-623. doi:https://doi.org/10.1016/j.ijpe.2013. 04.017

Tseng, S.-C., \& Hung, S.-W. (2014). A strategic decision-making model considering the social costs of carbon dioxide emissions for sustainable supply chain management. Journal of
Environmental Management, 133, 315-322.

doi:https://doi.org/10.1016/j.jenvman. 2013.11 .023

Witte, E. H., \& Davis, J. H. (2014). Group Decision Making and Quantitative Judgments: A Consensus Model. Dalam J. H. Davis, Understanding Group Behavior; Volume 1: Consensual Action By Small Groups (hal. 26-41). New York: Psychology Press.

doi:https://doi.org/10.4324/97813158 06372

Xu, Z. (2015). Uncertain Multi-Attribut Decision Making; Methods and Applications. New York: Springer.

Zhao, K., \& Smillie, L. D. (2014). The Role of Interpersonal Traits in Social Decision Making: Exploring Sources of Behavioral Heterogeneity in Economic Games. Personality and Social Psychological Review, 19(3), 277-302. doi:https://doi.org/10.1177/10888683 14553709

Zsambok, C. E., \& Klein, G. (2014). Naturalistic Decision Making. New York: Psychology Press. 